\title{
Effects of Dang-Gui-Bu-Xue-Tang, an herbal decoction, on iron uptake in iron-deficient anemia
}

This article was published in the following Dove Press journal:

Drug Design, Development and Therapy

2 March 2016

Number of times this article has been viewed

\author{
Guan-Cheng Huang ${ }^{1-3}$ \\ Shih-Yu Chen ${ }^{4}$ \\ Po-Wei Tsai ${ }^{5}$ \\ Jerome G Ganzon ${ }^{5}$ \\ Chia-Jung Lee ${ }^{6}$ \\ Her-Shyong Shiah ${ }^{7}$ \\ Ching-Chiung Wang ${ }^{4,5}$
}

'School of Medicine, College of Medicine, Taipei Medical University, Taipei, ${ }^{2}$ Division of Hematology and Oncology, Department of Internal Medicine, Yuan's General Hospital, ${ }^{3}$ Department of Leisure and Recreation Industry Management, College of Humanities and Management, Fooyin University, Kaohsiung, ${ }^{4}$ Graduate Institute of Pharmacognosy, College of Pharmacy, ${ }^{5}$ School of Pharmacy, College of Pharmacy, ${ }^{6} \mathrm{PhD}$ Program for Clinical Drug Discovery of Chinese Herbal Medicine, College of Pharmacy,

Taipei Medical University, ${ }^{7}$ Division of Hematology and Oncology, Department of Internal Medicine, Taipei Medical University Hospital, Taipei, Taiwan

Correspondence: Ching-Chiung Wang Graduate Institute of Pharmacognosy, College of Pharmacy, Taipei Medical University, 250 Wuxing Street, Taipei City I I0, Taiwan

Tel +886 22736 I66I ext $616 \mid$

Fax +886227329368

Email crystal@tmu.edu.tw
Abstract: Dang-Gui-Bu-Xue-Tang (DBT), a combination of Angelicae Sinensis Radix and Astragali Radix, is a widely used herbal decoction in traditional Chinese medicine primarily to promote or invigorate the "blood". In this study, we explored this ancient formulation and provide evidence of its blood-toning properties. We used the improvement iron uptake as promote or invigorate the "blood" indicator. Ferritin formation of Caco-2 cells in vitro assay and diet-induced anemia (DIA) in rat model were used to prove its improvement iron uptake and ameliorating effects. Finally, the iron-DBT interactions were measured by iron-binding assay. We first demonstrated DBT increased uptake of ferrous iron through the biosynthesis of ferritin by Caco- 2 cells and determined which complementary treatment would provide optimum results. Thereafter, effects of the treatment on improving the bioavailability of absorbed iron in the form of hemoglobin $(\mathrm{Hb})$ were established using a DIA-animal model. The results showed that DBT slightly improved $\mathrm{Hb}$ levels compared with the baseline $\mathrm{Hb}$ and pretreatment with DBT for 2 hours prior to supplementation with ferrous sulfate provided the greatest gain in $\mathrm{Hb}$ levels in DIA rats. However, DBT and ferrous sulfate were co-treated with Caco- 2 cell or DIA rats, the ferritin formation and $\mathrm{Hb}$ levels both were decreased. In iron-binding assay, the DBT extract influenced the free $\mathrm{Fe}$ (II) type in the $\mathrm{FeSO}_{4}$ solution. Therefore, we suggest that complementary treatment with DBT and iron supplementation can have a strong ameliorating effect on irondeficiency anemia in clinical settings, but needs a 2-hour interval of DBT administration prior to ferrous sulfate treatment.

Keywords: Dang-Gui-Bu-Xue-Tang, ferulic acid, iron uptake, ferritin, iron-deficiency anemia, herb-drug interaction

\section{Introduction}

Dang-Gui-Bu-Xue-Tang (DBT), a popular traditional Chinese medicine, was described as early as $1247 \mathrm{AD}$ during the Jin dynasty to have functions of tonifying the blood, and invigorating and replenishing "qi" (energy). ${ }^{1}$ The main components of this decoction are Angelicae sinensis Radix (dang-gui) and Astragali Radix (huang-qi) in a traditional ratio of 1:5. ${ }^{2}$ Studies showed that DBT improves hematopoiesis. ${ }^{3,4}$ It was also found that this traditional ratio of dang-gui and huang-qi was the most effective in promoting immune responses, such as by lymphocytes, macrophages, and interleukin-2. ${ }^{5}$ Immunomodulatory activities of DBT were also established in a tumor-bearing murine model of rats and were found to regulate $\mathrm{CD} 4^{+} / \mathrm{CD} 25^{+}$and tumor necrosis factor- $\alpha{ }^{6}$ Another study revealed that DBT can suppress the progression of diabetic nephropathy in rats with streptozotocin-induced diabetes. ${ }^{7}$ The anti-inflammatory properties of DBT were reported to have decreased inflammatory circulating markers in rats. ${ }^{8}$ Moreover, orthogonal studies revealed that the traditional way of extracting components of DBT, by boiling them in water, provided a high concentration of ferulic acid (FA). ${ }^{9}$ However, 
the ability of DBT to prevent iron-deficiency anemia (IDA) has not been explored. Therefore, we used a ferritin formation assay of Caco- 2 cells and an IDA rat model to evaluate the function of DBT in toning the blood.

IDA patients need to take iron supplements; therefore, we explored the interaction of DBT with iron-containing drugs. Caco-2 cells and IDA rats were treated only with DBT, an iron-containing drug only, DBT co-administered with an iron-containing drug, and DBT alternatively administered with iron. From these results, we are able to discuss how to take DBT in combination with iron.

\section{Materials and methods Preparation of the DBT}

Angelicae sinensis Radix (dang-gui) and Astragali Radix (huang-qi) were purchased from a traditional Chinese medicinal store in Taipei, Taiwan. The medicinal materials were authenticated by the non-profit organization Brion Research Institute of Taiwan. Dang-gui is the dried root of Angelica sinensis (Oliv.) Diels (Umbelliferae), no: AS-001. Huang-qi is the dried root of Astragalus membranaceus (Fisch.) Bge. (Leguminosae), no: AM-001. Voucher specimens (no: AS-0001 and AM-0001) were deposited at the Herbarium of the College of Pharmacy, Taipei Medical University.

The prescription of DBT was based on the unified formula announced by the Department of Chinese Medicine and Pharmacy, Ministry of Health and Welfare, Taiwan. The prescription of DBT includes dang-gui and huang-qi in a ratio of 1:5. Specifically, DBT was immersed in a 20-fold amount of distilled water, and boiled in a herb-extracting machine until half of the original amount was left. The extract was then filtered and freeze-dried. The yield of the extract was approximately $34.09 \%(\mathrm{w} / \mathrm{w})$. The freeze-dried DBT powder was stored at $-20^{\circ} \mathrm{C}$ until use.

\section{Phytochemical analysis of DBT Total polyphenol analysis}

The total polyphenol content was detected by the FolinCiocalteu method. ${ }^{10,11}$ The DBT extract was dissolved in double-distilled water $\left(\mathrm{ddH}_{2} \mathrm{O}\right)$. The diluted sample was mixed with Folin-Ciocalteu reagent and a 7.5\% aqueous $\mathrm{Na}_{2} \mathrm{CO}_{3}$ solution. After standing for 5 minutes at $50^{\circ} \mathrm{C}$, the absorbance was measured at $600 \mathrm{~nm}$ against water on an enzyme-linked immunosorbent assay (ELISA) reader. The amount of total polyphenol was expressed as gallic acid (GA) equivalents (mg GA/g sample) through a calibration curve prepared from standard amounts of GA (Sigma-Aldrich Co., St Louis, MO, USA, purity: 97.5\%-102.5\%).

\section{Total flavonol analysis}

The total flavonol content was determined by the vanillin assay. ${ }^{12}$ The vanillin reagent consisted of vanillin dissolved in $80 \% \mathrm{H}_{2} \mathrm{SO}_{4}$. The DBT extract was dissolved in $\mathrm{ddH}_{2} \mathrm{O}$. The diluted sample was mixed with the vanillin reagent. After incubation for 15 minutes at room temperature, the absorbance was measured at $530 \mathrm{~nm}$ against water on an ELISA reader. The amount of total flavonol was expressed as catechin equivalents (mg catechin/g sample) through a calibration curve prepared from standard amounts of catechin (Sigma-Aldrich Co., purity: >99\%).

\section{Total saponin analysis}

The total saponin content was determined by the sulfuric acid assay. ${ }^{13}$ The DBT extract was dissolved in $\mathrm{ddH}_{2} \mathrm{O}$, and the diluted sample was mixed with a $98 \% \mathrm{H}_{2} \mathrm{SO}_{4}$ solution. After being allowed to stand for 15 minutes at room temperature, the absorbance was measured at $414 \mathrm{~nm}$ against water on an ELISA reader. The amount of total saponin was expressed as diosgenin equivalents ( $\mathrm{mg}$ diosgenin/g sample) using a calibration curve prepared from standard amounts of diosgenin (Sigma-Aldrich Co., purity: >93\%).

\section{Ferulic acid analysis}

A high-performance liquid chromatography (HPLC) system consisted of a Shimadzu (Kyoto, Japan) LC-10ATvp liquid chromatograph equipped with a DGU-14A degasser, an FCV10ALvp low-pressure gradient flow control valve, an SIL10ADvp auto injector, an SPD-M10Avp diode array detector, and an SCL-10Avp system controller. Peak areas were calculated with Shimadzu Class-VP software (version $6.12 \mathrm{sp} 5$, Shimadzu, Kyoto, Japan). The mobile phase was composed of $0.05 \%$ trifluoroacetic acid-acetonitrile (v/v) at 80:20. A Purospher STAR RP-18e reversed-phase column (5 $\mu \mathrm{m}$, 250×4 mm ID, Merck, Darmstadt, Germany) and a Purospher STAR RP-18e guard column ( $4 \times 4$ mm ID) (Merck, Darmstadt, Germany) were used. The flow rate was $1.0 \mathrm{~mL} / \mathrm{min}$, with UV absorbance detection at $320 \mathrm{~nm}$. The analysis involved a $10 \mu \mathrm{L}$ of sample solution. The operation was carried out at an oven temperature of $40^{\circ}$ C. FA (Sigma-Aldrich Co., purity: $>99 \%$ ) was accurately weighed, dissolved, and double-diluted in HPLC-grade methanol to give serial concentrations in the range of $0.488-500 \mathrm{mg} / \mathrm{mL}$. Calibration curves were plotted after a linear regression of the peak areas.

\section{Ferritin formation assay of Caco-2 cells}

Caco-2 cells were obtained from the American Type Culture Collection (Rockville, MD, USA) and were cultured in 


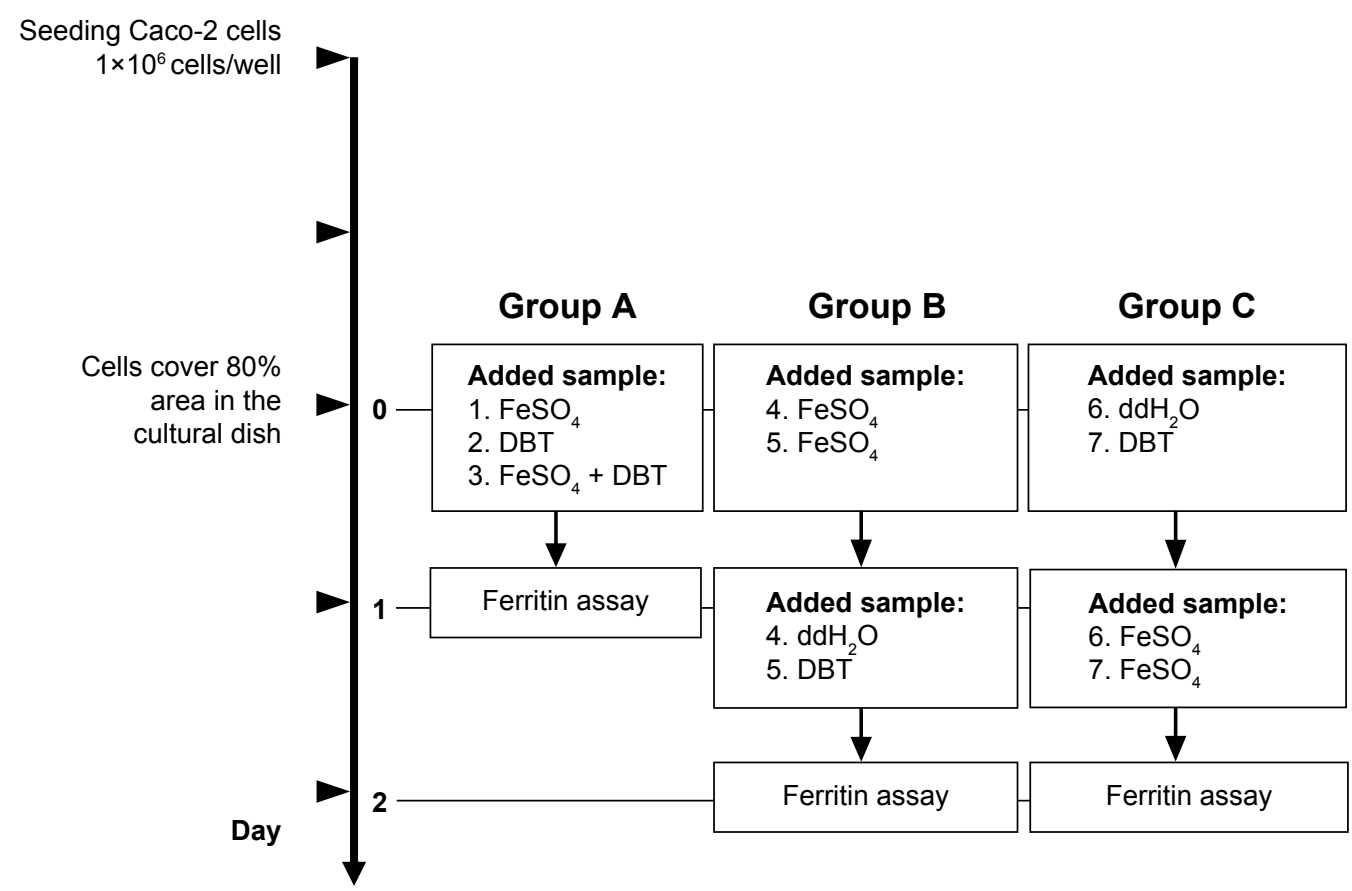

Figure I Experimental outline for the ferritin formation assay in Caco- 2 cells. Abbreviation: DBT, Dang-Gui-Bu-Xue-Tang.

Dulbecco's Modified Eagle's Medium containing 10\% heatinactivated fetal bovine serum, and 50 units $/ \mathrm{mL}$ penicillinstreptomycin. The culture dishes were incubated at $37^{\circ} \mathrm{C}$ in a humidified incubator containing $5 \% \mathrm{CO}_{2}$, and the medium was changed every 2 days. Cells were seeded in six-well plates, with each well containing $10^{6}$ cells, and cultured for 2 days. When cell growth covered $80 \%$ of the area of each well, the test samples were added (day 0). The sample design for ferritin formation in Caco-2 cells is described in Figure 1. Samples were allocated into three groups as following. Group A: single treatment of $\mathrm{FeSO}_{4}, \mathrm{DBT}$, or $\mathrm{FeSO}_{4}+\mathrm{DBT}$ co-treatment on day 0 and ferritin content analysis on day 1; group B: $\mathrm{FeSO}_{4}$ pretreatment on day 0 , then $\mathrm{ddH}_{2} \mathrm{O} / \mathrm{DBT}$ added on day 1 , and ferritin content analysis on day 2; group $\mathrm{C}$ : $\mathrm{ddH}_{2} \mathrm{O} / \mathrm{DBT}$ pretreatment on day 0 , then $\mathrm{FeSO}_{4}$ added on day 1 and ferritin content analysis on day 2 . Briefly, cells were harvested and lysed using radioimmunoprecipitation assay buffer, after which cells were frozen at $-20^{\circ} \mathrm{C}$ until being analyzed. The total protein content of the cell lysate was measured with a Coomassie Brilliant Blue G-250 binding assay (Bio-Rad DC Protein assay, Bio-Rad, Hercules, CA, USA). The ferritin amount was assessed with a commercially available enzyme immunoassay system (Amersham Pharmacia Biotech, Buckinghamshire, UK). Ferritin formation by Caco- 2 cells is dependent on the intracellular iron concentration. The index of cellular iron uptake is expressed as the ratio of ferritin (ng)/ protein (mg). The ethics committee/institutional review board of Taipei Medical University deemed it is not necessary to review and provide approval for commercial cell lines.

\section{Rats of the DIA model}

Male Sprague-Dawley (SD) rats weighing $65 \pm 5 \mathrm{~g}$ were obtained from the BioLASCO Taiwan Co., Ltd. (Yilan City, Taiwan), and maintained in plastic cages at $21^{\circ} \mathrm{C} \pm 2{ }^{\circ} \mathrm{C}$ with free access to pellet food and water. They were kept on a 12-hour light-dark cycle. All rats used in this experiment were cared for according to the Ethical Regulations on Animal Research of Taipei Medical University. All animal experiments were approved by the Animal Research of Taipei Medical University (permit no: LAC-97-0075). Test animals used in this study had body weights (BWs) of $<70 \mathrm{~g}$. SD rats were conditioned and fed the AIG-93G diet (an irondeficient diet, the formulation of which is given in Table 1) for 21 days. Blood was collected after 21 days from a tail vein into heparinized microcapillary tubes, and hemoglobin $(\mathrm{Hb})$ levels were measured using a KX-21N Hematology Analyzer (Sysmex, Kobe, Japan). SD rats with Hb levels of $<6 \mathrm{~g} / \mathrm{dL}$ were treated with test materials. The sample design for the diet-induced anemia (DIA) model is described in Figure 2. Test animals were grouped and treated with the following materials: group 1 (ddH $2 \mathrm{O}$ only), group $2\left(\mathrm{FeSO}_{4}\right.$ only), group 3 (DBT $250 \mathrm{mg} / \mathrm{kg} \mathrm{BW}$ ), group 4 (DBT $500 \mathrm{mg} / \mathrm{kg} \mathrm{BW}$ ), group 5 (DBT $500 \mathrm{mg} / \mathrm{kg} \mathrm{BW}$ co-treated with $1 \mathrm{mg} \mathrm{FeSO} /$ $\mathrm{kg} \mathrm{BW}$ ), and group 6 (pretreated with DBT $500 \mathrm{mg} / \mathrm{kg} \mathrm{BW}$ 
Table I Formula of the AIN-93G diet

\begin{tabular}{ll}
\hline Item & $\mathbf{( g / k g )}$ \\
\hline Casein & 200 \\
Cornstarch & 629.486 \\
Soybean oil & 70 \\
Fiber & 50 \\
Mineral mix AIN-93G, Fe-free & 35 \\
Vitamin mix AIN-93G & 10 \\
L-Cysteine & 3 \\
Choline bitartrate & 2.5 \\
Total & 1,000 \\
\hline
\end{tabular}

Notes: ${ }^{a}$ The AIN-93G iron-free mineral mix contains the following components (in $\mathrm{g} / \mathrm{kg}$ mixture): calcium carbonate (357), potassium phosphate monobasic (I57), tri-potassium citrate monohydrate ( 102 ), $\mathrm{NaCl}$ (74), $\mathrm{K}_{2} \mathrm{SO}_{4}$ (46), $\mathrm{MgO}$ (24), zinc carbonate (1.65), manganese carbonate (0.63), cupric carbonate $(0.3), \mathrm{KIO}_{3}$ $(0.0 \mathrm{I})$, sodium selenite $(0.0 \mathrm{I} 025)$, chromium potassium sulfate $\mathrm{I} 2$ hydrate $(0.275)$, ammonium paramolybdate 4 hydrate $(0.00795)$, sodium meta-silicate 9 hydrate (I.45), lithium chloride $(0.0174)$, boric acid $(0.0815)$, sodium fluoride $(0.0635)$, nickel carbonate $(0.0318)$, ammonium vanadate $(0.0066)$, and finely powdered sucrose (235). ' $T$ The AIN-93G vitamin mix contains the following components (in $\mathrm{g} / \mathrm{kg}$ feed): thiamine $\mathrm{HCl}(0.6)$, riboflavin (0.6), pyridoxine $\mathrm{HCl}(0.7)$, nicotinic acid (3.0), D-calcium pantothenate (I.6), folic acid (0.2), D-biotin (0.02), cyanocobalamin (0.0025), retinyl palmitate $(400,000 \mathrm{IU}), \mathrm{dl}-\alpha(\mathrm{all}-\mathrm{rac})$-tocopheryl acetate $(7,500 \mathrm{IU})$, cholecalciferol (I00,000 IU), K-I (0.075), and finely powdered sucrose (974.655). Abbreviations: AIN, American Institute of Nutrition; IU, international unit.

followed at a 2-hour interval by $1 \mathrm{mg} \mathrm{FeSO}_{4} / \mathrm{kg} \mathrm{BW}$ ). Six rats were assigned to each group, and materials were administered once a day for 28 days. After treatment for 28 days, blood samples from each test animals were collected, and $\mathrm{Hb}$ levels were measured. The gain in $\mathrm{Hb}$ was expressed as the difference in $\mathrm{Hb}$ levels from the initial treatment (day 21 ) and the last treatment (day 49).

\section{Iron-binding analysis}

Ferrous ion $\left(\mathrm{Fe}^{2+}\right)$ was detected by a colorimetric reagent. The colorimetric reagent contained $0.025 \%$ bathophenanthroline disulfonic acid and $2 \mathrm{M}$ sodium acetate. $\mathrm{FeSO}_{4}$ was accurately weighed, dissolved in $\mathrm{ddH}_{2} \mathrm{O}$, and serially diluted to provide a concentration range of $0.375-12 \mathrm{mg} / \mathrm{mL}$. Each diluted solution of $\mathrm{FeSO}_{4}$ was combined with $500 \mu \mathrm{g} / \mathrm{mL}$ DBT and $30 \mu \mathrm{g} / \mathrm{mL}$ of FA (the principal component in DBT). The colorimetric reagent was added and incubated at $37^{\circ} \mathrm{C}$ for 16 hours, after which the absorbance was measured at $530 \mathrm{~nm}$ against water in an ELISA reader.

\section{Statistical analysis}

Results are presented as the mean \pm standard deviation from three independent experiments. A one-way analysis of variance in SPSS version 12 software (SPSS Inc., Chicago, IL, USA) was used to analyze the results. Results were considered statistically significant when $P<0.05$.

\section{Results}

\section{Phytochemical contents of DBT}

The phytochemical analysis of the water extract of DBT (Table 2) by the Folin-Ciocalteu method showed that it contained $6.51 \pm 0.29 \mathrm{mg} / \mathrm{g}$ total polyphenol compounds. Total flavonoids were found to be $2.31 \pm 0.05 \mathrm{mg} / \mathrm{g}$ using the vanillin test method. The innate iron II content of the DBT water extract was determined using the inductively

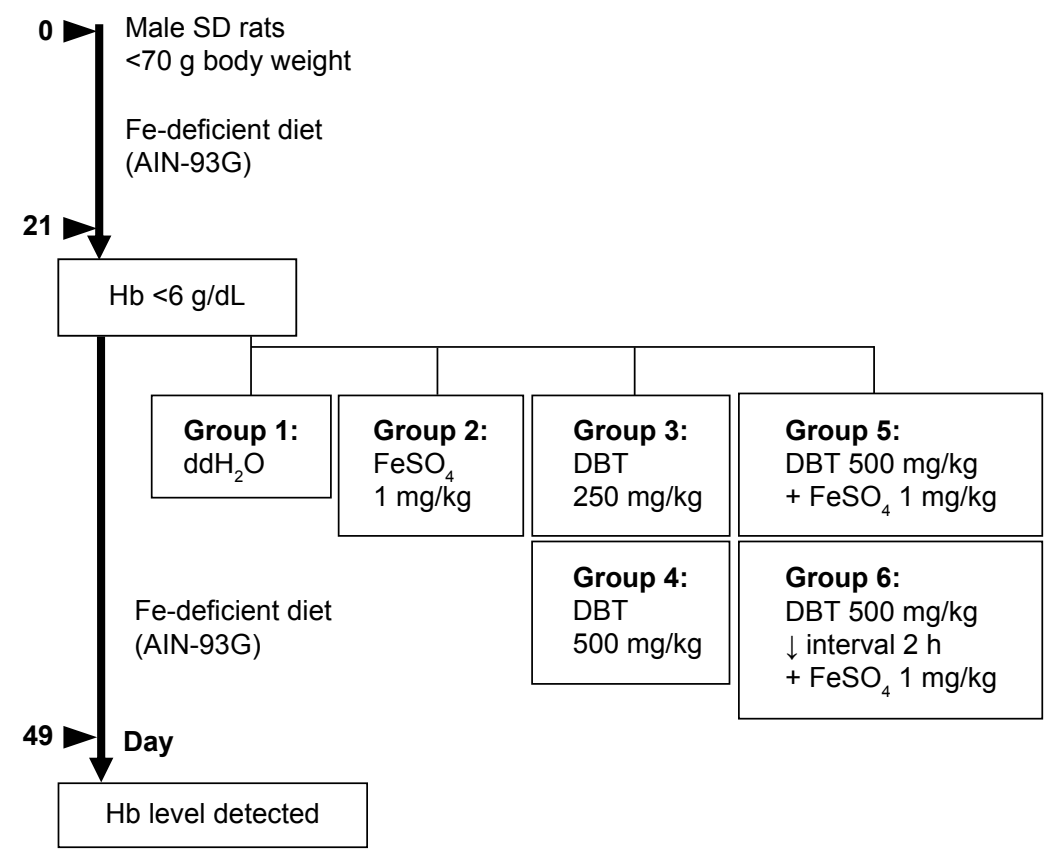

Figure 2 Animal model of iron-deficiency anemia.

Abbreviations: AIN, American Institute of Nutrition; DBT, Dang-Gui-Bu-Xue-Tang; Hb, hemoglobin; SD, Sprague-Dawley; h, hours. 
Table 2 Phytochemical compositions of the DBT extract

\begin{tabular}{lllllll}
\hline Item & Method & Equivalent & $\begin{array}{l}\text { Concentration } \\
\text { range }(\mu \mathrm{g} / \mathbf{m L})\end{array}$ & Linear equation & $\mathbf{r}^{2}$ & $\begin{array}{l}\text { Content } \\
(\mathbf{m g} / \mathbf{g})\end{array}$ \\
\hline Total polyphenol & Folin-Ciocalteu & Gallic acid & $3.906-500$ & $y=0.0056 x+0.039$ & 0.9999 \\
Total flavonol & Vanillin & Catechin & $3.906-250$ & $y=0.0134 x+0.1161$ & 0.9996 & $2.31 \pm 0.29$ \\
Total saponin & Sulfuric acid & Diosgenin & $7.812-1,000$ & $y=0.0025 x+0.0767$ & 0.9970 & $34.48 \pm 3.99$ \\
Total Fe ${ }^{2+}$ & ICP-MS & - & - & - & - & 0.0145 \\
Ferulic acid & HPLC-UV system & Ferulic acid & $0.488 \sim 500$ & $y=59550 x+47568$ & 1.0000 & $30.83 \pm 0.29$ \\
\hline
\end{tabular}

Abbreviations: DBT, Dang-Gui-Bu-Xue-Tang; ICP-MS, inductively coupled plasma mass spectrometry; HPLC-UV, high-performance liquid chromatography with ultraviolet detector; $r^{2}$, coefficient of determination.

coupled plasma mass spectrometry (ICP-MS) method, and provided a total ferrous content of $14.5 \mu \mathrm{g} / \mathrm{g}$. FA, which was determined to be the principal component of DBT, was found to be $30.83 \pm 0.29 \mathrm{mg} / \mathrm{g}$ using the HPLC-UV method. Interestingly, the concentration of total saponin in the DBT water extract $(34.48 \pm 3.99 \mathrm{mg} / \mathrm{g}$ ) was comparable to the FA content. Total polyphenol, total flavonoids, $\mathrm{Fe}^{2+}$ content, and total saponin are respectively expressed as GA, catechin, $\mathrm{FeSO}_{4}$, and diosgenin equivalents. All calibration curves exhibited good linearity (0.9970-1.0000).

\section{Stimulated ferritin formation effects of DBT in Caco-2 cells}

Following the protocol as outlined in Figure 1, we measured the formation of ferritin in Caco-2 cells. Results are shown in Figure 3, where a significant dose-dependent increase in ferritin (hollow bars) was observed with DBT even when no $\mathrm{FeSO}_{4}$ was added. When Caco-2 cells were cultured with the DBT extract combined with $\mathrm{FeSO}_{4}, \mathrm{FeSO}_{4}$ promoted ferritin formation that the DBT extract inhibited (Figure 3). Related to this (results in gray bars), with low-concentration $\mathrm{FeSO}_{4}(25 \mathrm{ng} / \mathrm{mL})$ co-treatment with DBT, a dose-dependent increase in ferritin formation was also observed, but this was only significant at $500 \mu \mathrm{g} / \mathrm{mL}$. However, none of the DBT-FeSO ${ }_{4}(25 \mathrm{ng} / \mathrm{mL})$ groups exhibited an enhanced compartment with the DBT groups. A dramatic increase in ferritin was observed with $\mathrm{FeSO}_{4}$ treatment at $25 \mu \mathrm{g} / \mathrm{mL}$ $\mathrm{FeSO}_{4}$ (black bars), which implies increased iron uptake could also be achieved at this high $\mathrm{FeSO}_{4}$ dosage. However, with high-concentration $\mathrm{FeSO}_{4}(25 \mu \mathrm{g} / \mathrm{mL})$ co-treatment with DBT, ferritin formation began to decrease in a dosedependent manner. These results show that the inhibitory effects of the DBT extract increased when co-treated with higher concentrations of $\mathrm{FeSO}_{4}$.

To establish whether interval administration of DBT and $\mathrm{FeSO}_{4}$ could improve iron uptake by Caco- 2 cells by

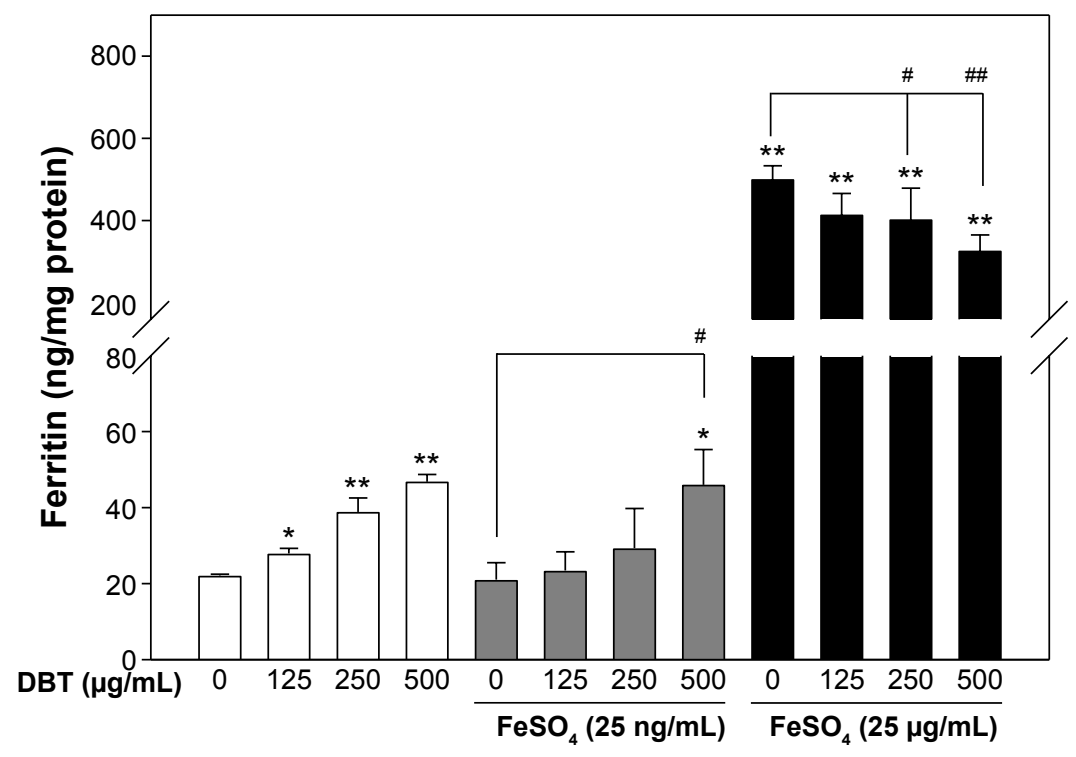

Figure 3 Ferritin protein formations by Caco-2 cells and after co-treatment with DBT at low and high concentrations of FeSO .

Notes: Bars represent the mean \pm standard deviation of three independent experiments. Statistically significantly differs from cell-only group at $* P<0.05$; $* * P<0.00$ I. Statistically significantly differs from the $\mathrm{FeSO}_{4}$-only group at $\# P<0.05 ;{ }^{\#} P<0.00 \mathrm{I}$.

Abbreviation: DBT, Dang-Gui-Bu-Xue-Tang. 


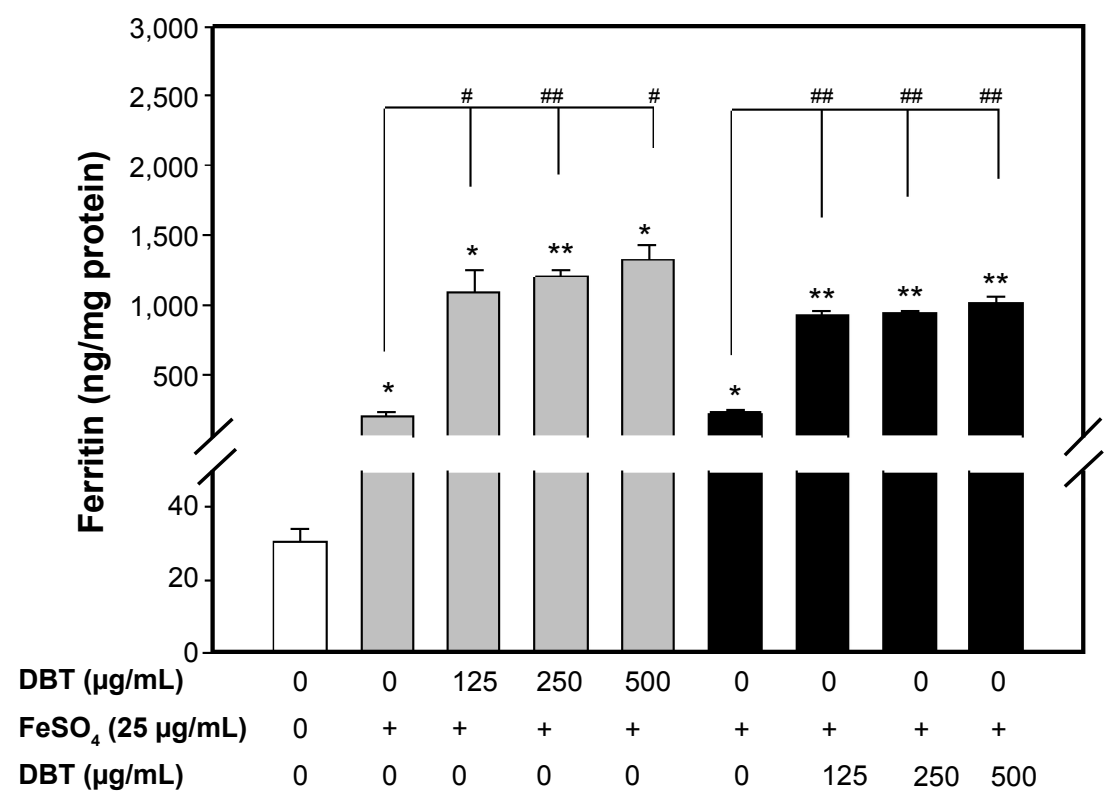

Figure 4 Ferritin protein formations by Caco-2 cells with an interval between administration of DBT and FeSO 4 .

Notes: Bars represent the mean \pm standard deviation of three independent experiments. Statistically significantly differs from the cell-only group at $* P<0.05 ; * * P<0.00 \mathrm{I}$. Statistically significantly differs from the $\mathrm{FeSO}_{4}$-only group at ${ }^{\# P}<0.05 ;{ }^{\# P} P 0.001$.

Abbreviation: DBT, Dang-Gui-Bu-Xue-Tang.

monitoring ferritin formation, alternate treatments with DBT- $-\mathrm{FeSO}_{4}$ and $\mathrm{FeSO}_{4}-\mathrm{DBT}$ were performed (Figure 4). Baseline ferritin formation ( $\mathrm{ng} / \mathrm{mg}$ protein) was established for non-pretreated (hollow bars), DBT-pretreated (gray bars), and $\mathrm{FeSO}_{4}$-pretreated (black bars) Caco-2 cells. DBT concentrations of 125,250 , and $500 \mu \mathrm{g} / \mathrm{mL}$ were administered either as pre- or post-treatment with respect to ferrous sulfate which was administered at a fixed concentration of $25 \mu \mathrm{g} / \mathrm{mL}$. A 1-day interval was applied in either case. Both pretreatment and post-treatment groups showed high iron uptake as reflected by ferritin formation. Results in Figure 4 suggest that DBT enhanced $\mathrm{FeSO}_{4}$ to promote ferritin formation. The promoting effects of $\mathrm{FeSO}_{4}$ were more enhanced when DBT was added before $\mathrm{FeSO}_{4}$.

\section{The ameliorating effects of DBT in diet-induced anemia in rat}

Further investigation of the bioavailability effects of pretreatment versus co-treatment by determining the gain in $\mathrm{Hb}(\mathrm{g} / \mathrm{dL})$ in the DIA-animal model is shown in Figure 5. The baseline $\mathrm{Hb}$ level induced by the iron-deficient diet (AIN-93G) in rats was recorded. It can clearly be seen that treatment only with DBT (either 250 or $500 \mathrm{mg} / \mathrm{kg}$ ) slightly improved $\mathrm{Hb}$ levels compared with the baseline $\mathrm{Hb}$. On the other hand, co-treatment of $\mathrm{FeSO}_{4}(1 \mathrm{mg} / \mathrm{kg})$ with DBT $(500 \mathrm{mg} / \mathrm{kg})$ showed no significant improvement in $\mathrm{Hb}$ levels of the test animals, and $\mathrm{Hb}$ levels even decreased compared with those of rats treated with $\mathrm{FeSO}_{4}$ only. This result supports the observed decrease in ferritin formation for the high-concentration $\mathrm{FeSO}_{4}$-co-treated group (black bars) in Figure 3, due to induction of a drug-herb interaction. However, the 2-hour interval prior of $\mathrm{FeSO}_{4}$ administration prior to DBT treatment provided the greatest improvement in $\mathrm{Hb}$ levels in DIA rats. This was also found to be significant compared with rats treated only with $\mathrm{FeSO}_{4}$. Therefore, we used an iron-binding analysis to explore the mechanism of $\mathrm{FeSO}_{4}-\mathrm{DBT}$ extract interactions.

\section{Ferulic acid as the bioactive marker of DBT, stimulated ferritin formation in Caco-2 cells}

The DBT extract contained $30.8 \mathrm{mg}$ FA/g (Table 2). Therefore, we used $15 \mu \mathrm{g} / \mathrm{mL}$ FA which was equivalent to 500 $\mu \mathrm{g} \mathrm{FA} / \mathrm{mL}$ DBT extract. Investigations of the effects of increased concentrations of FA on ferritin formation of Caco-2 cells were performed, and results are summarized in Figure 6. A dose-dependent increase in ferritin formation was well established by increasing the FA concentration from 7.5 to $30 \mu \mathrm{g} / \mathrm{mL}$ in the presence of $25 \mu \mathrm{g} / \mathrm{mL} \mathrm{FeSO}_{4}$, but only $30 \mu \mathrm{g} / \mathrm{mL}$ FA significantly promoted ferritin formation compared with $\mathrm{FeSO}_{4}$ only (Figure 6). However, there was no apparent change in ferritin production in the absence of $\mathrm{FeSO}_{4}$ even though FA had increased as depicted by the hollow bars. The above-mentioned results argue that FA 


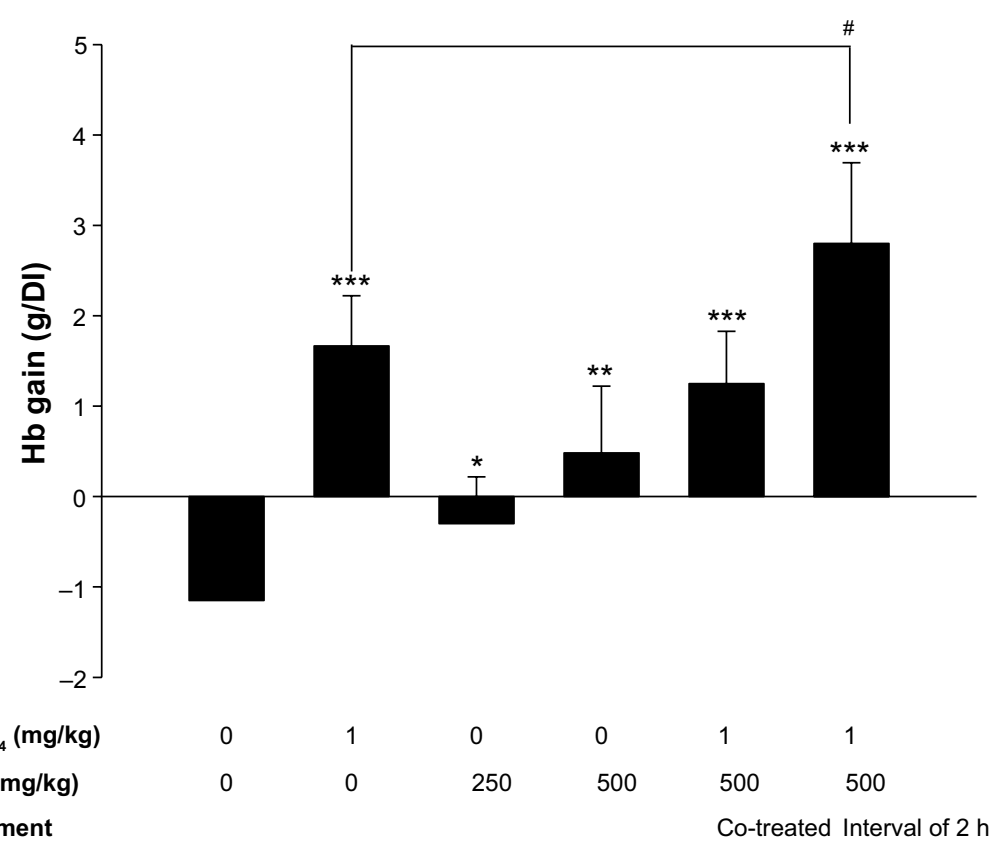

Figure 5 The gain in $\mathrm{Hb}$ in DIA rats with an interval of $2 \mathrm{~h}$ between the administration of DBT and FeSO ${ }_{4}$.

Notes: Bars represent the mean \pm standard deviation of six rats per group. Statistically significantly differs from the blank group at $* P<0.05$; $* * P<0.00$ I; $* * * P<0.000$ I. Statistically significantly differs from the $\mathrm{FeSO}_{4}$-only group at $\# P<0.05$.

Abbreviations: DBT, Dang-Gui-Bu-Xue-Tang; DIA, diet-induced anemia; Hb, hemoglobin; h, hours.

could be a bioactive marker, but it was not the only active component.

\section{The interaction effects between iron II and DBT or ferulic acid}

On the other hand, a possible interaction of DBT with iron II was explored in Figure 7. Here one can see that the baseline calibration curve for the increasing concentration of $\mathrm{FeSO}_{4}$ only $(\bullet)$ was lower than the calibration curve drawn from the solution with the combination of $\mathrm{FeSO}_{4}$ and $30 \mu \mathrm{g} / \mathrm{mL}$ FA ( $\mathbf{\nabla})$. This result suggests that the presence of FA, the relatively low $\mathrm{pH}$ value condition, would help the dissociation of $\mathrm{FeSO}_{4}$ to $\mathrm{Fe}^{2+}$ and result in increment of iron II detection. Surprisingly, the presence of $500 \mathrm{mg} / \mathrm{mL}$ of DBT significantly decreased the calibration curve of $\mathrm{FeSO}_{4}(\ominus)$. In summary, our results suggest

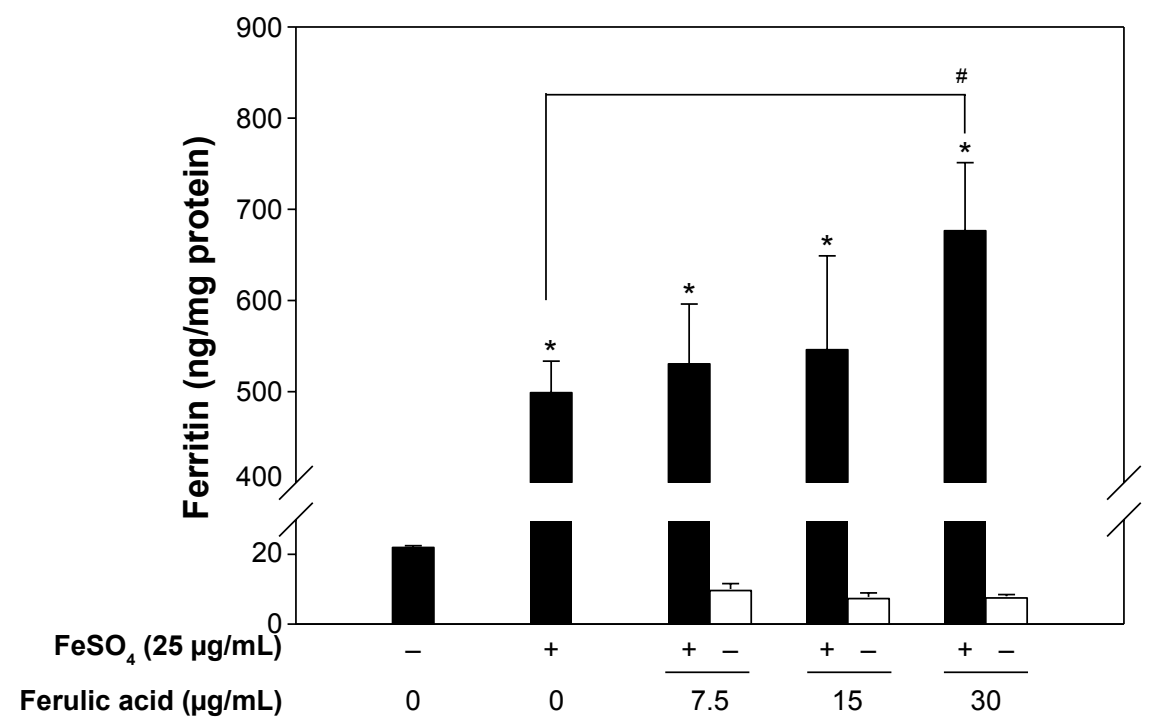

Figure 6 Ferritin protein formation by Caco-2 cells when treated with $\mathrm{FeSO}_{4}$ in combination with ferulic acid.

Notes: Bars represent the mean \pm standard deviation of three independent experiments. Statistically significantly differs from the cell-only group at $* P<0.05$. Statistically significantly differs from the $\mathrm{FeSO}_{4}$-only group at ${ }^{\#} P<0.05$. 


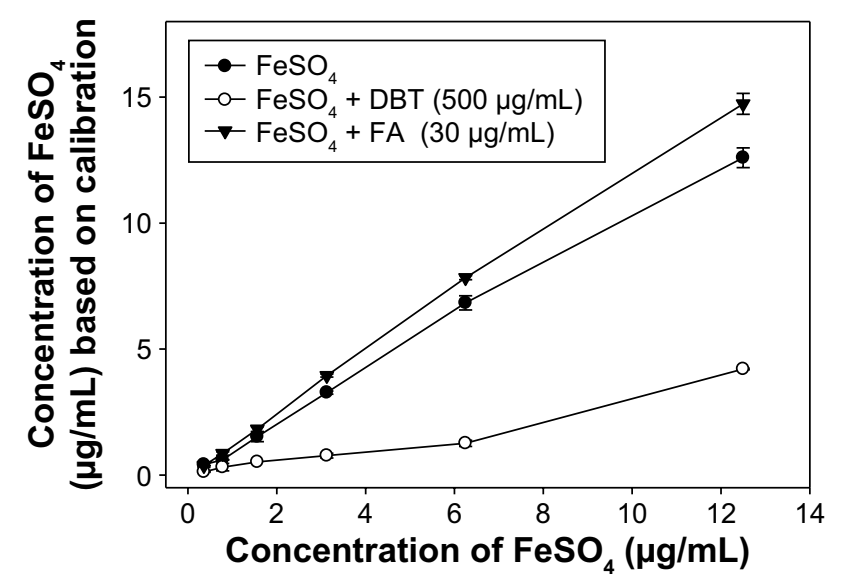

Figure 7 Effects of FA and DBT on the colorimetric determination of $\mathrm{FeSO}_{4}$ concentration

Notes: Results are shown as the mean \pm standard deviation of three independent experiments, each performed in triplicate.

Abbreviations: DBT, Dang-Gui-Bu-Xue-Tang; FA, ferulic acid.

that the DBT extract influenced the free Fe(II) type in the $\mathrm{FeSO}_{4}$ solution.

\section{Discussion}

Caco-2 cells are a popular and widely used cell line to investigate in vitro iron uptake. ${ }^{14}$ It was also established that monitoring ferritin production by Caco- 2 cells provides comparable results to intrinsic radiolabeling of food and food products in iron uptake studies. ${ }^{14,15}$ Thus, this method was used in our study. As outlined in Figure 1, it was necessary to determine the response of Caco-2 cells in each of the components of this experiment, such as with $\mathrm{ddH}_{2} \mathrm{O}$, $\mathrm{FeSO}_{4}, \mathrm{DBT}$, and the latter two in combination to establish which components have effects on iron uptake by this cell line. However, it was found that co-treatment with a low concentration of $\mathrm{FeSO}_{4}(25 \mathrm{ng} / \mathrm{mL})$ and DBT produced no significant difference in ferritin formation compared with DBT only (Figure 3). The addition of $\mathrm{FeSO}_{4}(25 \mathrm{ng} / \mathrm{mL})$ in combination with DBT (gray bars) produced the same level of ferritin as did treating cells with DBT only (hollow bars). We also found that the ferritin formation response of Caco-2 cells with DBT only was due to the innate iron content of the DBT formulation as depicted by the total $\mathrm{Fe}^{2+}$ concentration analysis by ICP-MS (Table 2). However, a dose-dependent increase in ferritin formation was observed at these low levels of innate iron and with the addition of iron to the cells. In contrast, at a high concentration $(25 \mu \mathrm{g} / \mathrm{mL})$ of $\mathrm{FeSO}_{4}$ co-treated with increasing doses of DBT, a dose-dependent decline in ferritin formation was observed (black bars). This decrease in iron uptake by Caco-2 cells was thought to be due to the high innate saponin content of the DBT formulation (Table 2).
Previous studies established that complexation of various naturally occurring saponins has a negative effect on iron availability for absorption and uptake in in vitro and in vivo experiments. ${ }^{16,17}$ According to the study from Milgate and Roberts, ${ }^{18}$ the insoluble saponin-iron complex would affect the iron availability for absorption and uptake, while it is the possible mechanism of this phenomenon.

To further improve iron uptake by Caco-2 cells, an alternate pretreatment with $\mathrm{DBT}-\mathrm{FeSO}_{4}$ was designed, in which 1-day pretreatment was carried out before the second drug was administered (Figure 4). It was observed that if the cell lines were first pretreated with DBT then after 1 day $25 \mu \mathrm{g} / \mathrm{mL}$ of $\mathrm{FeSO}_{4}$ was added, a dose-dependent increase in ferritin formation occurred. The obvious dose-dependent decrease observed at this concentration of added $\mathrm{FeSO}_{4}$ in Figure 3 was eliminated by the pretreatment process. It was thought that pretreatment was necessary to prevent the saponins from complexing with the added iron. Moreover, polyphenol being good antioxidants may prevent the oxidation of $\mathrm{Fe}^{2+}$ to the unabsorbable ferric form. Furthermore, the interval may be a necessary procedure to allow production of free phenols in the gastrointestinal tract.

Because pretreatment was established to prevent complexation of DBT components with ferrous ion, it was necessary to develop a treatment process that would be feasible if developed in clinical settings. Thus, an interval of 2 hours was applied to DIA rats for DBT-FeSO ${ }_{4}$ administration. It can clearly be seen in Figure 5 that among other treatments, animals treated with the 2-hour interval exhibited the most significant gain in $\mathrm{Hb}$. This strongly suggests that the designed program of administration greatly improved the bioavailability of iron. Pretreatment also ensured that saponins were eliminated through the intestines, and thus complexation with the added iron was prevented, because it was found to be unabsorbed in the small intestine. ${ }^{19}$

To further validate that $\mathrm{FA}$, the major component of DBT, contributes to the observed increased iron absorption, we returned to ferritin formation by Caco- 2 cells. Figure 6 clearly shows that only FA assisted the absorption of added $\mathrm{FeSO}_{4}$ at $25 \mu \mathrm{g} / \mathrm{mL}$ which produced a significant dose-dependent increase in ferritin formation. This was further supported by results provided in Figure 7, where the highest colorimetric concentration of $\mathrm{FeSO}_{4}$ was due to $\mathrm{FeSO}_{4}+\mathrm{FA}$. Moreover, the large decline in available $\mathrm{Fe}^{2+}$ observed in the $\mathrm{FeSO}_{4}+$ DBT curve strongly suggests that indeed DBT-saponins interfered with the absorption of ferrous ions. Therefore, in conclusion, this study has established the ameliorating effects of the 2-hour interval between the administration of 
DBT prior to $\mathrm{FeSO}_{4}$ on ferritin formation in vitro by Caco-2 cells and in vivo on the gain of $\mathrm{Hb}$ by DIA rats. We strongly suggest that incorporating DBT as a complementary drug to $\mathrm{FeSO}_{4}$ treatment can improve $\mathrm{Hb}$ levels of iron-deficient patients in clinical settings.

\section{Acknowledgments}

This work was supported by grants from Division of Hemato-oncology, Department of Internal Medicine, Yuan's General Hospital, and Taipei Medical University (103YGH-TMU-02-1).

\section{Disclosure}

The authors report no conflicts of interest in this work.

\section{References}

1. Wang P, Liang YZ. Chemical composition and inhibitory effect on hepatic fibrosis of Danggui Buxue decoction. Fitoterapia. 2010;81: 793-798.

2. Liu IM, Tzeng TF, Liou SS. A Chinese herbal decoction, Dang Gui Bu Xue Tang, prepared from Radix Astragali and Radix Angelicae sinensis, ameliorates insulin resistance induced by a high-fructose diet in rats. Evid Based Complement Alternat Med. 2011;2011:248231.

3. Wang XL, Wang T, Wang YN. Effect of danggui buxue decoction on the hemopoiesis reconstruction of mouse transplanted by the muscle satellite cell receptor. Zhongguo Zhong Xi Yi Jie He Za Zhi. 2011;31: 1093-1096.

4. Zheng KY, Choi RC, Xie HQ, et al. The expression of erythropoietin triggered by danggui buxue tang, a Chinese herbal decoction prepared from Radix Astragali and Radix Angelicae Sinensis, is mediated by the hypoxia-inducible factor in cultured HEK293T cells. J Ethnopharmacol. 2010;132:259-267.

5. Gao QT, Cheung JK, Li J, et al. A Chinese herbal decoction, Danggui Buxue Tang, activates extracellular signal-regulated kinase in cultured T-lymphocytes. FEBS Letters. 2007;581:5087-5093.

6. Hsieh CC, Lin WC, Lee MR, et al. Dang-Gui-Bu-Xai-Tang modulated the immunity of tumor bearing mice. Immunopharmacol Immunotoxicol. $2003 ; 25: 259-271$.
7. Zhang YW, Xie D, Xia B, Zhen RT, Liu IM, Cheng JT. Suppression of transforming growth factor-beta1 gene expression by Danggui buxue tang, a traditional Chinese herbal preparation, in retarding the progress of renal damage in streptozotocin-induced diabetic rats. Horm Metab Res. 2006;38:82-88.

8. Zhang H, Chen S, Deng X, Yang X, Huang X. Danggui-Buxue-Tang decoction has an anti-inflammatory effect in diabetic atherosclerosis rat model. Diabetes Res Clin Pract. 2006;74:194-196.

9. Song ZH, Ji ZN, Lo CK, et al. Chemical and biological assessment of a traditional Chinese herbal decoction prepared from Radix Astragali and Radix Angelicae Sinensis: orthogonal array design to optimize the extraction of chemical constituents. Planta Med. 2004;70: $1222-1227$.

10. Huang D, Ou B, Prior RL. The chemistry behind antioxidant capacity assays. J Agric Food Chem. 2005;53:1841-1856.

11. Everette JD, Bryant QM, Green AM, Abbey YA, Wangila GW, Walker RB. Thorough study of reactivity of various compound classes toward the Folin-Ciocalteu reagent. J Agric Food Chem. 2010;58: $8139-8144$.

12. He X, Liu D, Liu RH. Sodium borohydride/chloranil-based assay for quantifying total flavonoids. J Agric Food Chem. 2008;56: 9337-9344.

13. Hiai S, Oura H, Nakajima T. Color reaction of some sapogenins and saponins with vanillin and sulfuric acid. Planta Med. 1976;29: 116-122.

14. Glahn RP, Lee OA, Yeung A, Goldman MI, Miller DD. Caco-2 cell ferritin formation predicts nonradiolabeled food iron availability in an in vitro digestion/Caco-2 cell culture model. J Nutr. 1998;128: $1555-1561$.

15. Viadel B, Perales S, Barberá R, Lagarda MJ, Farré R. Ferritin synthesis by Caco-2 cells as an indicator of iron bioavailability: application to milk-based infant formulas. Food Chem. 2007;102:925-931.

16. Southon S, Johnson IT, Gee JM, Price KR. The effect of Gypsophila saponins in the diet on mineral status and plasma cholesterol concentration in the rat. Br J Nutr. 1988;59:49-55.

17. West LG, Greger JL, White A, Nonnamaker BJ. In vitro studies on saponin-mineral complexation. J Food Sci. 1978;43:1342-1343.

18. Milgate J, Roberts DCK. The nutritional \& biological significance of saponins. Nutr Res. 1995;15:1223-1249.

19. Gestetner B, Birk Y, Tencer Y. Soybean saponins. Fate of ingested soybean saponins and the physiological aspect of their hemolytic activity. J Agric Food Chem. 1968;16:1031-1035.

\section{Publish your work in this journal}

Drug Design, Development and Therapy is an international, peerreviewed open-access journal that spans the spectrum of drug design and development through to clinical applications. Clinical outcomes, patient safety, and programs for the development and effective, safe, and sustained use of medicines are a feature of the journal, which

\section{Dovepress}

has also been accepted for indexing on PubMed Central. The manuscript management system is completely online and includes a very quick and fair peer-review system, which is all easy to use. Visit http://www.dovepress.com/testimonials.php to read real quotes from published authors. 